\title{
Review of the genus Opazon Haliday, 1857 (Hymenoptera: Diapriidae: Belytinae) in the fauna of Russia
}

\section{Обзор рода Opazon Haliday, 1857 (Hymenoptera: Diapriidae: Belytinae) в фауне России}

\author{
V.G. Chemyreva \\ B.Г. Чемырева
}

\begin{abstract}
Zoological Institute, Russian Academy of Sciences, St. Petersburg, Russia. E-mail:diapriidas.vas@gmail.com Зоологический институт Российской академии наук, Санкт-Петербург, Россия.
\end{abstract}

KEY WORDS: Hymenoptera, Diapriidae, Belytinae, Pantolytini, Opazon, Russia, Palaearctic Region, new records, key.

КЛЮЧЕВЫЕ СЛОВА: Нymenoptera, Diapriidae, Belytinae, Pantolytini, Opazon, Россия, Палеарктическая область, новые находки, определительный ключ.

ABSTRACT. Four species of the genus Opazon Halliday, 1857 are found to occur in Russia, one of which $O$. incrassatum (Thomson, 1859) recorded for the Russian fauna for the first time. All known Palaearctic species of Opazon are reviewed and keyed. Colour illustrations are provided to all species.

РЕЗЮМЕ. Установлено, что четыре вида из рода Opazon Halliday, 1857 встречаются в России, один из которых $O$. incrassatum (Thomson, 1859) указывается для фауны России впервые. Дан обзор и определительный ключ для всех известных палеарктических видов. Для каждого вида подготовлены цветные иллюстрации.

\section{Introduction}

The genus Opazon Halliday, 1857 includes small (1.5$2.5 \mathrm{~mm}$ ) diapriid wasps from the tribe Pantolytini (Hymenoptera: Diapriidae: Belytinae). Biology and hosts of these parasitoids are still unknown. Only five species of the genus are known in the World fauna, four of which, Opazon apertum (Kieffer, 1908), O. incrassatum (Thomson, 1859), O. parvulum (Haliday, 1857) and O. frigidum Macek, 1977, were described from the Palaearctic region, and one, O. conicum (Ashmead, 1893) from the Nearctic region [Johnson, 1992; Macek, 1995]. In the key to Diapriidae of the USSR M. Kozlov [1978] recorded two species of Opazon in the fauna of Russia, O. apertum from Ural and O. parvulum from the European part. J. Macek [1995] in his revision of the Palaearctic Opazon species proposed some new synonyms, useful key and diagnosis for the all valid species. Moreover he recorded O. frigidum for
Russian fauna from Yamal Peninsula (this is the typelocality of the species) [Macek, 1995].

During our study of material from the many localities in Russia and several neighboring countries, we have researched all known Palaearctic species, analyzed and estimated morphological variations and proposed original illustrate key to the Palaearctic species. The new key proposed here is adapted for determination Opazon species in the Eastern Palaearctic fauna (center and east of the European part of Russia, Ural, Siberia and Far East).

\section{Material and methods}

This work is based on the insect collection of the Zoological Institute of the Russian Academy of Sciences, St Petersburg, Russia (ZIN), the Zoological Museum of the Moscow State University, Moscow, Russia (ZMUM), the National Museum, Prague, Czech Republic (NMPC) and the National History Museum, University of Tartu, Tartu, Estonia (TUZ). Material for this study was collected by yellow pan traps and by net sweeping. Morphological terminology and abbreviations follow Nàumann [1982], Masner, García [2002], Yoder [2004] and Yoder et al., [2010]. The measurements mostly follow Yoder [2004] but the measurements of venation are used here after Chemyreva and Kolyada [2019a, b].

New distribution records are marked with an asterisk (*). The general distribution of species follows Nixon [1957] and Macek [1995]. The genus Opazon can be recognized in the Palaearctic fauna using the generic key by Nixon [1957], Kozlov [1978] and Macek [1989].

How to cite this article: Chemyreva V.G. 2021.Review of the genus Opazon Haliday, 1857 (Hymenoptera: Diapriidae: Belytinae) in the fauna of Russia // Russian Entomol. J. Vol.30. No.1. P.78-83. doi: 10.15298/ rusentj.30.1.09 
All photographs were obtained using a Leica M165 stereomicroscope equipped with a Leica DFC450 camera. Image stacking was performed with Helicon Focus 5.0.

\section{Results}

Genus Opazon Haliday, 1857

Opazon Haliday, 1857: 170. Type species: Belyta (Opazon) parvula Haliday, 1857.

Meuselia Kieffer, 1909. Type species: Meuselia fuscicornis Kieffer, 1909. Synonymised by Macek, 1995.

Promeuselia Kieffer, 1910. Type species: Rhynchopsilus clausus Kieffer, 1908. Synonymised by Nixon, 1957.

Rhynchopsilus Kieffer, 1908. Type species: Rhynchopsilus apertus Kieffer, 1908. Synonymised by Macek, 1995.

DIAGNOSIS. Small parasitoids $(1.7-3.0 \mathrm{~mm})$; pale brown to black. Head in frontal view with genae converging towards mouthparts; mouthparts hypognathous; mandibles beak-like, bidentate; clypeus strongly convex, higher than its width; labrum triangular; tentorial pits situated in deep depression; antennal shelf prominent, toruli close to each other. Female antenna 15-segmented, incrassate apically; male antenna 14segmented with cylindrical antennomers and A3 mostly modified. Mesosoma usually a little higher than wide; pronotum with prominent pronotal shoulders, with sharp and distinct epomia; pronotal pits absent, epomia not interrupted; pronotal collar sculptured, often with distinct transversal keel; mesonotum convex with complete and deep notauli; propodeum slightly transverse with simple median keel; plicae distinct throughout and weakly projecting posteriorly. Venation with radial cell closed or partly open apically (Figs 1415); veins C, Sc, marginal, postmarginal, stigmal, radial and basal veins tubular; marginal vein longer than radial cell and distance from marginal vein to basal vein. Petiole subcylindrical, a little longer than wide, finely sculptured; T2 with five deep and short grooves at base; S2 without any prominences anteriorly; female metasoma fusiform, compressed at posterior third, with pygidium extended and down curved; hypopygium enlarged, surmounting epipygium at sides; ovipositor long, as long as metasoma without petiole; gonapophyses slender.

RELATIONSHIPS. The genus Opazon belongs to Pantolytina subtribes and closely related to the genus Pantolyta Foerster, 1856, differing from it mainly by distinctly beaklike shape of mandibles. Moreover, the male genitalia of Opazon have apex of volsella fused with digitus, in difference from Pantolyta where volsella is free.

\section{Key to Palaearctic species of Opazon Haliday}

1. A1 with weakly prominent lamellae in both sex (Figs 3,4 ), slender, more than 6.0 times as long as wide in female and 5.0 in male. Mandibles $0.60-0.75$ times as long as pleurostomal distance (Figs 3-4). Head in frontal view as height as wide (Figs 3-4); temples in dorsal view short (Fig. 16)

- A1 with strongly prominent lamellae in both sexes (Figs 1,2 ), robust, 3.6-4.5 times as long as wide in female (Figs $1-2$ ) and 3.2-3.8 in male (Figs 9-10). Mandibles 0.821.20 times as long as pleurostomal distance (Figs 1-2). Head in frontal view and temples in dorsal view elongate (Figs 1-2, 16, 18)

2. A11 and A12 in females as wide as long to elongate; female antenna slender (Fig. 7); A3 in males unmodified, straight (Fig. 12) ............ O. parvulum (Haliday, 1857)

- A11 and A12 in females distinctly transverse; female antenna stout (Fig. 6); A3 in males modified, strongly emarginate (Fig. 11) ............ O. frigidum Macek, 1995

3. Eyes prominent of outline of head in dorsal view. Mandible very long, longer than pleurostomal distance (Fig. 1) O. apertum (Kieffer, 1908)

- Eyes not prominent of outline of head in dorsal view (Fig. 18). Mandible about as long as pleurostomal distance to weakly shorter (Fig. 2)

O. incrassatum (Thomson, 1859)

REMARK. Some difficulties in separation of $O$. parvulum and $O$. frigidum females are present. The females both
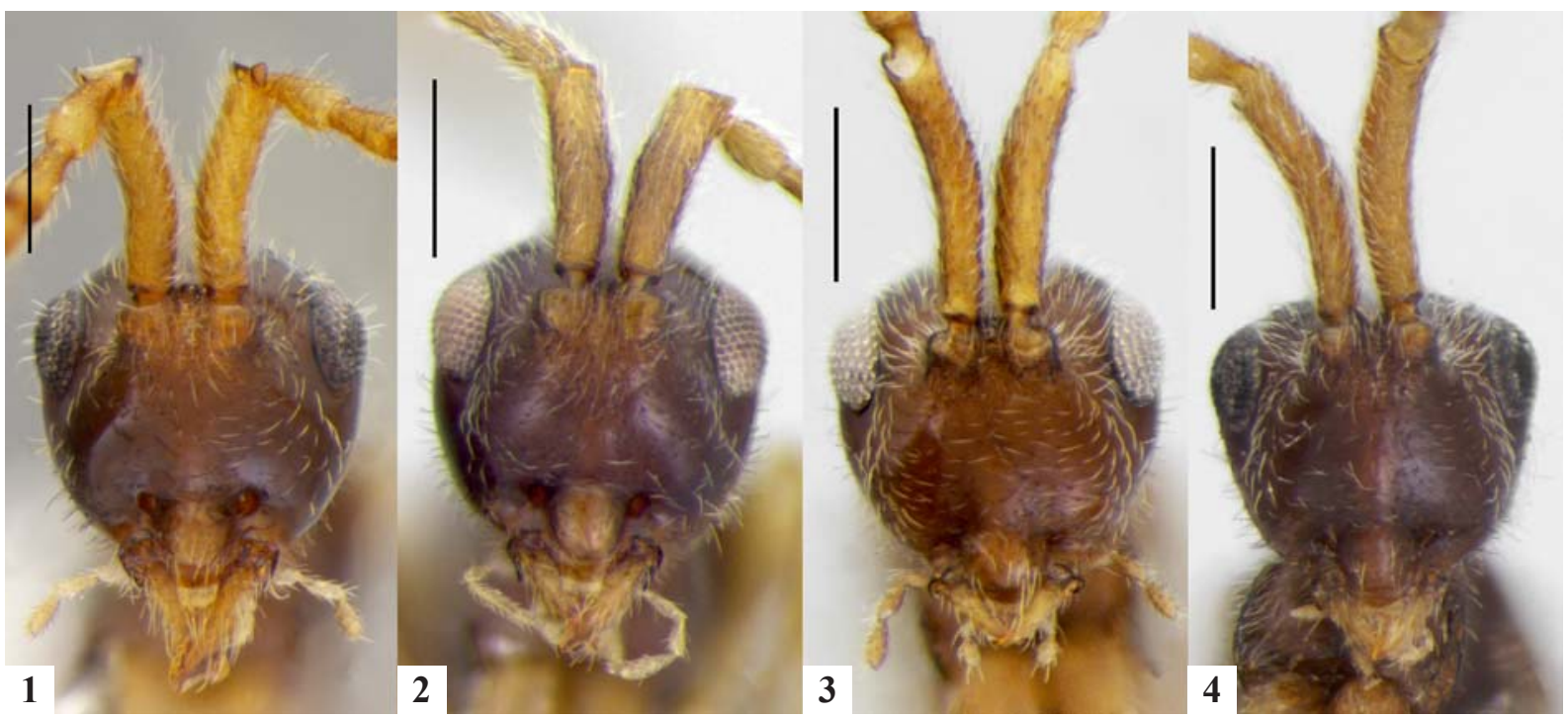

Figs 1-4. Opazon spp., head in frontal view (females): 1 - O. apertum; 2 - O. incrassatum; 3 - O. frigidum; 4 - O. parvulum. Scale bars: $0.2 \mathrm{~mm}$. 0,2 мм.

Рис. 1-4. Opazon spp., голова спереди (самки): 1 - O. apertum; 2 - O. incrassatum; 3 - O. frigidum; 4 - O. parvulum. Масштаб: 


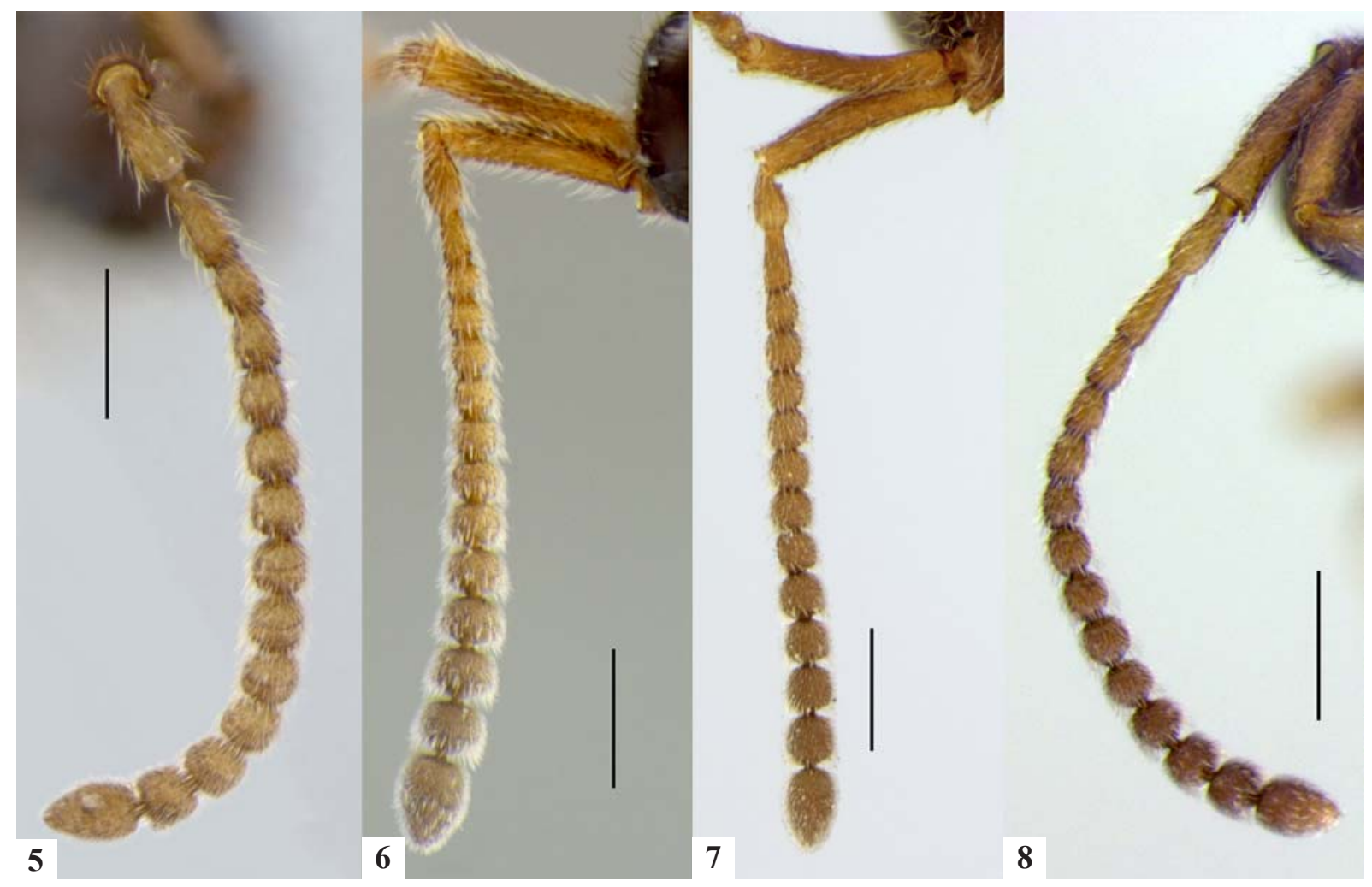

Figs 5-8. Opazon spp., female antennae: $5-$ O. apertum; $6-$ O. frigidum; 7 - O. parvulum; $8-O$. incrassatum. Scale bars: $0.2 \mathrm{~mm}$. Рис. 5-8. Opazon spp., антенны самок: 5 - O. apertum; 6 - O. frigidum; 7 - O. parvulum; 8 - O. incrassatum. Масштаб: 0,2 мм.
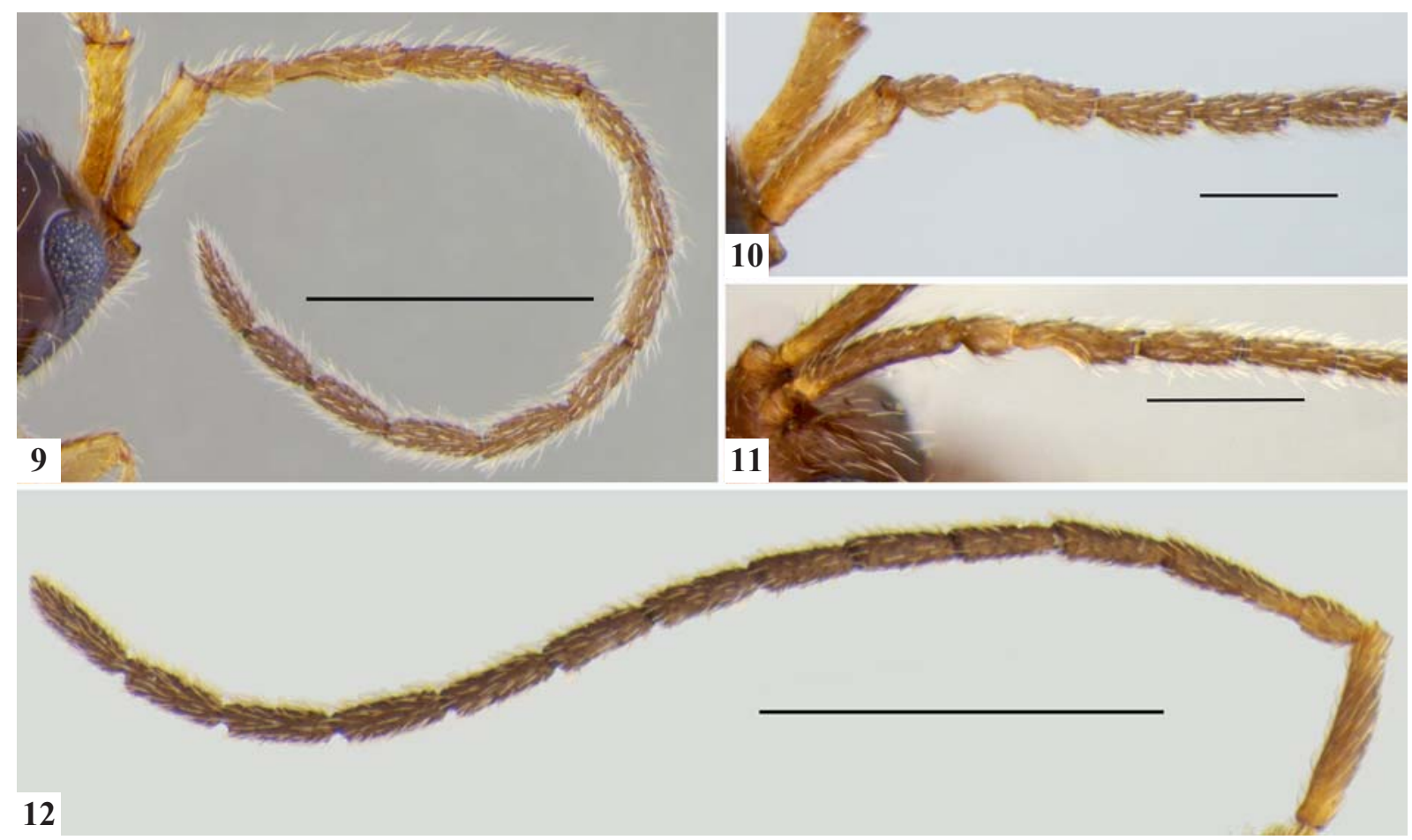

Figs 9-12. Opazon spp., male antennae: $9-$ O. apertum $; 10-$ O. incrassatum $; 11-O$. frigidum $; 12-$ O. parvulum. Scale bars: 0.2 $\mathrm{mm}(9,12), 0.5 \mathrm{~mm}(11,12)$.

Рис. 9-12. Opazon spp., антенны самцов: 9 - O. apertum; $10-$ O. incrassatum; $11-$ O. frigidum; $12-$ O. parvulum. Масштаб: 0,2 мм $(9,12), 0,5$ мм $(11,12)$. 


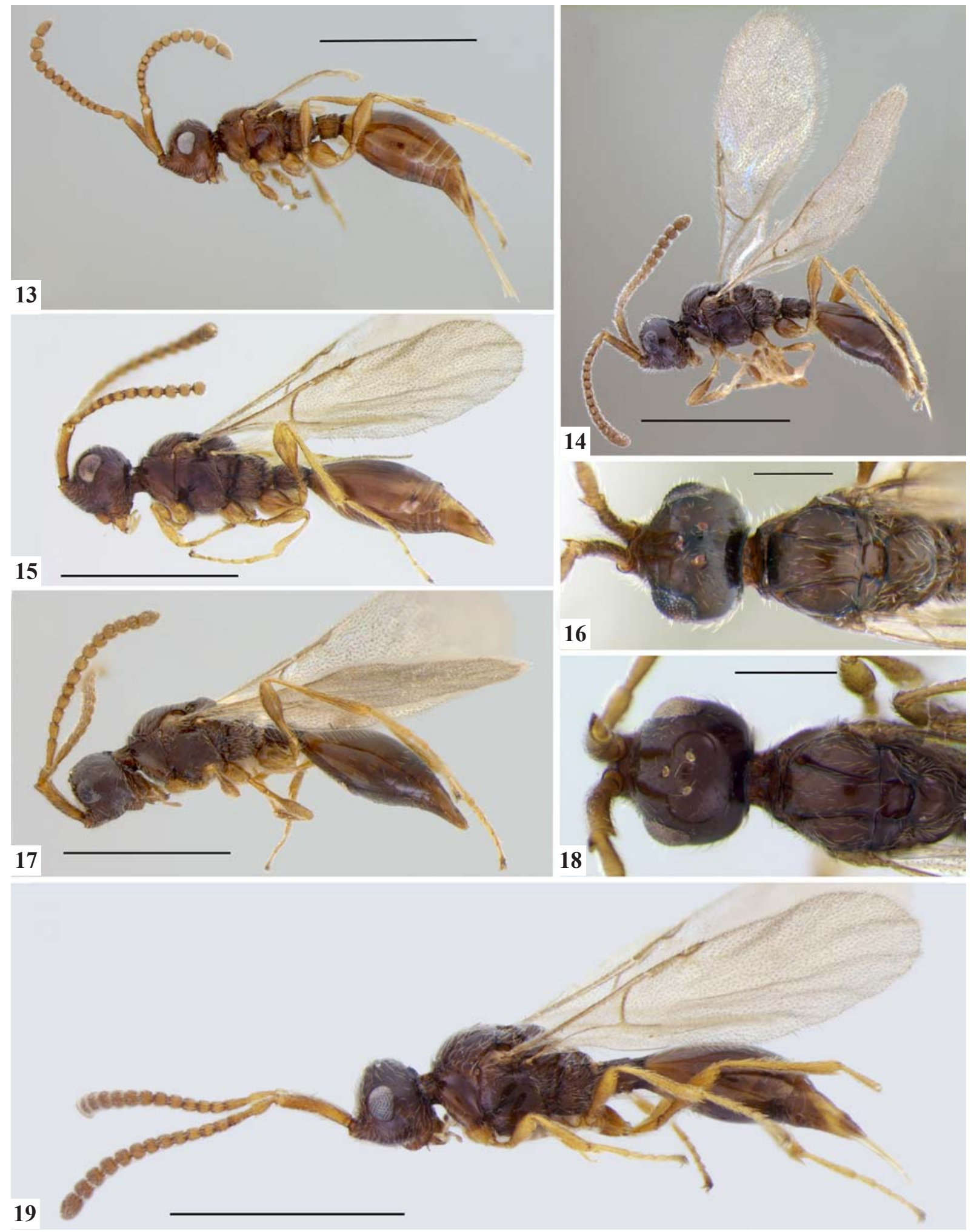

Figs 13-19. Opazon spp.: 13-14 - O. frigidum; 15, 18 - O. incrassatum; 16, 19 - O. parvulum; 17 - O. apertum; 13-15, 17, $19-$ lateral habitus; 16,18 - head in dorsal view. Scale bars: $0.2 \mathrm{~mm}(16,18), 1.0 \mathrm{~mm}(13-15,17,19)$.

Рис. 13-19. Opazon spp.: 13-14 - O. frigidum; 15, 18 - O. incrassatum; 16, 19 - O. parvulum; 17 - O. apertum; 13-15, 17, $19-$ габитус сбоку; 16, 18 - голова сверху. Масштаб: 0,2 мм (16, 18), 1,0 мм (13-15, 17, 19). 
species can be recognized in the Western Palaearctic fauna (Europe and west of the European part of Russia) using the key suggested by Macek [1995], but in the Eastern fauna (center and east of the European part of Russia, Ural, Siberia and Far East) the species better determinate by using characters described in the key above.

\section{Opazon apertum (Kieffer, 1908)}

Figs 1, 5, 9, 17.

Rhynchopsilus apertus Kieffer, 1908.

Opazon opertum Chemyreva, 2019: 37 (erratum).

MATERIAL EXAMINED: Lithuania. 1 , $3 \mathrm{O}^{7} \mathrm{O}^{7}$ (ZIN): vicinity of Vilnius, 17.VI.1971, V. Tobias leg. Estonia. $2 \mathrm{O}^{7} \mathrm{O}^{7}$ (TUZ): Paluküla $58.2571^{\circ} \mathrm{N} 26.9326^{\circ} \mathrm{E}$, YPT, 15.VI.2017, V. Soon leg.; 2 $\sigma^{7} \sigma^{7}$ (ZIN): Võru. Russia. $0^{7}$ : Leningradskaya Area, Ladoga Lake Station, 13.VI.1983, S. Belokobylskij leg.; 5 우, 109 O $^{7} \mathrm{O}^{7}$ (ZIN, ZMUM): Moscow Area, Moscow City, Krylatskoe, Rublevskiy forest, 1-30.VI.2004, V. Kolyada leg.

VARIATIONS. Radial cell well developed (close or open at apex) to strongly reduced to transparent point.

DISTRIBUTION. England, Germany, Italy, Poland, Czech Republic, Austria, *Lithuania, *Estonia, Russia (*European part, Ural).

\section{Opazon incrassatum (Thomson, 1859)}

Figs 2, 8, 10, 15, 18.

Belyta (Opazon) incrassata Thomson, 1859.

MATERIAL EXAMINED. Russia. o" (ZIN): Komi Republic, Seyda River, estuary, 13.VIII.1972, D. Kasparyan leg.; ㅇ (ZIN): Perm' Prov., Kamenka Village, 18.VI.1962, A. Ponomorenko leg.

VARIATIONS. No distinct variation of the morphological characters was found in the studied specimens.

DISTRIBUTION. England, Sweden, Finland, Czech Republic, Hungary, *Russia (European Part).

\section{Opazon frigidum Macek, 1995 \\ Figs 3, 6, 11, 13, 14 .}

Opazon frigidum Macek, 1995: 83.

MATERIAL EXAMINED: Estonia. $\sigma^{7}$ (TUZ): Torma vald, 13.VI.1988, G. Dlusskiy leg.; + (TUZ): Tartu, Raadi gravel pit, $58.393^{\circ} \mathrm{N} 26.737^{\circ} \mathrm{E}, 23 . I X .2017$, V. Soon leg.; $0^{7}$ (TUZ): Tähtvere raba $58.3972^{\circ} \mathrm{N} 26.6318^{\circ} \mathrm{E}, \mathrm{YPT}, 16 . \mathrm{VI} .2017$, V. Soon leg. Russia $\sigma^{7}$ (ZMUM): Kaliningrad Area, Kurshskaya Kosa (= Curonian Spit)

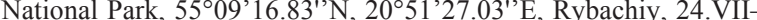
4.VIII.2006, V. Kolyada leg.; + (ZIN): Murmansk Area, Bol'shoy Vudyavr Lake, 20.VIII.1931, A. Fridolin leg.; ( $($ ZIN): Komi Republic, $70 \mathrm{~km} \mathrm{~S}$ of Vorkuta, 11.VIII.1972, D. Kasparyan leg.; 9 (ZIN): $5 \mathrm{~km} \mathrm{NW}$ of Sivaya Maska Station, 7.VIII.1961, K. Gorodkov leg.; 3 O $^{7} \sigma^{7}$ (ZIN): Leningradskaya Area, Roshchino, 25.VI.1980, V. Trjapitzin leg; OT (ZMUM): Vladimir Area, Petushinskiy District, Gnezdino Village, 18.VI.1971, V. Alekseev leg.; $\sigma^{7}$ (ZMUM): Moscow Area, Moscow City, 5.VII.1988, V. Kolyada leg.; O (ZMUM): Mytistshi, 19.VI.1933, V. Kostylev leg.; $;$ (ZIN): Samara Area, Kinel' District, Domashka Village, 18.VIII.2008, V. Che-

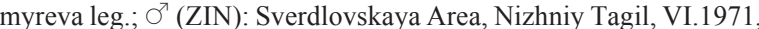
Lebedkina leg.; + , $5 \mathrm{O}^{7} \mathrm{O}^{7}$ (ZMUM): Krasnoyarsk Prov., Taymyr Peninsula, Agapa River, 13.VIII.1973, V. Zherikhin and I. Sukacheva leg.; (ZMUM): Taymyr Peninsula, Khatanga, Antardakh Village, 5.VIII.1971, V. Zherikhin and I. Sukacheva leg.; $O^{7}$ (ZMUM) Taymyr Peninsula, Khatanga, Syndaska Bay, 16.VIII.1971, A. Rasnitsyn and V. Zherikhin leg.; 7 우 (ZMUM): Taymyr Peninsula, Putorana Plateau, $550 \mathrm{~m}, 23$.VII-13.VIII.1996, A. Babenko and O. Makarova leg.;,$+ 4 O^{7} O^{7}$ (ZMUM): Taymyr Peninsula, near Taymyr Lake, 25.VII-18.VIII.1994, soil traps, K. Makarov leg.; + (ZIN): Buryatia, Malyy Kunaley, Khilok River, 5.VII.1970, D. Kasparyan leg.; ㅇ (ZIN): Republic of Yakutia, Amga Village, 8.VIII.1925, V. Bianki leg.; + (ZIN): $50 \mathrm{~km}$ NWW of Yakutsk, 3.VII.1970, D. Kasparyan leg.; ( (ZMUM): Central Yakutia, 5.VIII.1990, V. Alekseev leg.;,$+ 3 \bigcirc^{7} O^{\top}$ (ZMUM): Republic of Yakutia, Srednekolymsk, $154^{\circ} \mathrm{E} 67^{\circ} 30^{\prime} \mathrm{N}, 18 . \mathrm{VI}-13 . \mathrm{VII} .1991$, V. Alekseev leg.; + , $\mathrm{O}^{\top}$ (ZMUM): Amur Area, Zeya Nature Reserve, 8-9.VIII.1978, V. Alekseev and S. Kurbatov leg.; + (ZMUM): Amur Area, Tukuringra mountains, 12.VIII.1981, V. Alekseev leg.; 24 오, 15 O $^{7} \sigma^{7}$ (ZIN): Khabarovsk Prov., Udyl' Lake, 2931.VIII.1970, D. Kasparyan leg.; o (ZMUM): Sakhalin Area, Sakhalin Is., Firsovo, 28.VI.1972, I. Sukacheva leg. Kazakhstan. 2 우 (ZIN): Karaganda Province, Kenderlyk River, 16.VI.1961, V. Tobias leg. Mongolia. $20^{7} 0^{7}$ (ZIN): Tarbagatay Mountains, Uliyn-Daba Pass, 17.VII.1975, V. Sugonyaev leg.

VARIATIONS. Body dark brown to pale brown; radial vain obliterated to distinct at apex, $0.50-0.83$ times as long as marginal vein; mandibles $0.6-0.7$ times as long as pleurostomal distance. Females pterygopolymorphic (Figs 13, 14). Female A4-A7 as long as wide to weakly transverse.

DISTRIBUTION. Sweden, Poland, Czech Republic, *Estonia, Russia (European part, *Ural, Western Siberia, *Eastern Siberia, *Far East), *Kazakhstan, *Mongolia.

\section{Opazon parvulum (Haliday, 1857)}

Figs 4, 7, 12, 16, 19 .

Belyta (Opazon) parvula Haliday, 1857.

Opazon parvulus Chemyreva, 2019: 37 (erratum).

MATERIAL EXAMINED. Estonia. $\sigma^{7}$ (TUZ): Külasema, $58.6398^{\circ} \mathrm{N} 23.161^{\circ} \mathrm{E}, 22 . V I .2016$, V. Soon leg.; $\mathrm{O}^{\mathrm{T}}$ (TUZ): Abruka, $58.159^{\circ} \mathrm{N} 22.517^{\circ} \mathrm{E}, 27 . \mathrm{VII} .2017$, V. Soon leg. Ukraine. $0^{7}$ (ZIN): Donetsk Area, "Khomutovskaya Step"” Nature Reserve, 17.V.1974, D. Kasparyan leg. Russia. o (ZMUM): Kaliningrad Area, Kurshs-

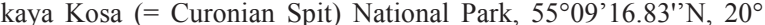

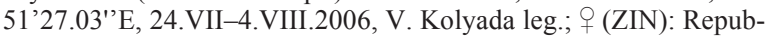
lic of Karelia, Keret' Village, 14.VIII.1980, N. Storozheva leg.; 2 우, 7 O$^{7} 0^{7}$ (ZMUM): Belgorod Area, near Shebekino, 3.VII.1988, V. Kolyada leg.; + (ZMUM): Belgorod Area, Alexeevskiy District, 25.IX.1987, V. Kolyada leg.; 3 O $^{7} \sigma^{7}$ (ZMUM): Moscow Area, Moscow City, Bitsa Park, 1-10.VI.1994, V. Kolyada leg.; O (ZMUM): Lyubertsy Distr., Kraskovo Station, 28.VII.2007, K. Tomkovich leg.; + (ZIN): Samara Area, Kinel' District, near Domashka, 18.VIII.2008, V. Chemyreva leg.; $4 \mathrm{O}^{7} \mathrm{O}^{7}$ (ZIN): Chelyabinsk Area, Ilmenskiy Nature Reserve, 13-18.VII. 1958, V. Tobias leg.; $\sigma^{7}$ (ZMUM): Krasnoyarsk Prov., Taymyr Peninsula, Agapa River, 13.VIII.1973, V. Zherikhin, I. Sukacheva leg.; 5 우, o (ZMUM): Republic of Yakutia, Srednekolymsk, $154^{\circ} \mathrm{E} 67^{\circ} 30^{\prime} \mathrm{N}, 18$.VI13.VII.1991, V. Alekseev leg.; $2 \mathrm{O}^{7} \mathrm{O}^{7}$ (ZIN): Republic of Yakutia, Troitskoe, estuary Olekma River, 9 and 12.VII.1970, D. Kasparyan leg. Armenia. OT (ZIN): Erevan, 17.V.1971, D. Kasparyan leg.

VARIATIONS. Body dark brown to pale brown; radial vein partly obliterated to distinct at apex, 1.7-2.6 times as long as marginal vein (the development of radial vein might be discordant in the same specimen [Macek, 1995]); mandibles $0.7-0.8$ times as long as pleurostomal distance. Female A5-A8 subquadrate to elongate, A9-A14 as wide as long to transverse.

DISTRIBUTION. England, Finland, Sweden, Germany, Poland, Czech Republic, Slovakia, Austria, Hungary, *Estonia, *Ukraine, Russia (European part, *Ural, Western and Eastern *Siberia), *Armenia, Japan.

Acknowledgements. I am very thankful to Dr Sergey A. Belokobylskij (ZIN) for his help with the first draft of manuscript and constant support, to Dr Alexandr P. Rasnitsyn (Palaeontological Institute RAS, Moscow, Russia) for giving me an opportunity to prepare insect images. I am especially grateful to Dr Jan Macek (National Museum, Prague, Czech Republic) for his helpful assistance, the reference collection of the Opazon species. Thanks to Dr Villu Soon who kindly granted the additional material for this study. This study was supported by the Russian Foundation for Basic Research (projects Nos 19-04-00027 and 18-34-00088). 


\section{References}

Chemyreva V.G., Kolyada V.A. 2019a. Review of the genus Pantolyta Förster, 1857 (Hymenoptera: Diapriidae, Pantolytini) from Russia, with description of three new species // Zoosystematica Rossica. Vol.28. No.1. P.163-176.

Chemyreva V.G., Kolyada V.A. 2019b. Review of the genus Synacra Foerster (Hymenoptera, Diapriidae: Pantolytini) in the Palaearctic region, with description of new species // Entomological Review. Vol.99. No.9. P.1339-1358.

Chemyreva V.G. 2019. Family Diapriidae // S.A. Belokobylskij, K.G. Samartsev, A.S. Il'inskaya (eds.). Annotated catalogue of the Hymenoptera of Russia. Volume II. Apocrita: Parasitica. Proceedings of the Zoological Institute of the Russian Academy of Sciences. Supplement 8. Zoological Institute RAS, St Petersburg. P.35-40.

Haliday A.H. 1857. Note on a peculiar form of the ovaries observed in a hymenopterous insect, constituting a new genus and species of the family Diapriidae // Natural History Review. Vol.4. P.166-174.

Johnson N.F. 1992. Catalog of World species of Proctotrupoidea, exclusive of Platygastridae (Hymenoptera) // Memoirs of the American Entomological Institute. Vol.52. P.1-825.

Kozlov M.A. 1978. [Fam. Diapriidae] // V.A. Trjapitzin (ed.). Opredelitel' nasekomykh Evropeyskoy chasti SSSR [Keys to the insects of the European part of USSR]. Vol.3. Part 2. Leningrad: Nauka. P.548-608 [in Russian].

Macek J. 1989. Studies on the Diapriidae (Hymenoptera, Proctotrupoidea). Part 1. Taxonomic remarks on the subfamily Belytinae with particular reference to the Pantolytini // Annales Zoologici. Vol.42. P.353-362.

Macek J. 1995. Revision of genus Opazon Haliday in Europe (Hymenoptera, Diapriidae) // Folia Heyrovskiana. Vol.3. Nos78. P.21-42.

Masner L., García J.L. 2002. The genera of Diapriinae (Hymenoptera, Diapriidae) in the New World // Bulletin of the American Museum of Natural History. Vol.268. P.1-138.

Naumann J. 1982. Systematics of Australian Ambositrinae (Hymenoptera, Diapriidae), with synopsis on non-Australian genera of the subfamily // Australian Journal of Zoology. Vol.85. P.1239.

Nixon G.E.J. 1957. Hymenoptera, Diapriidae, subfamily Belytinae // Handbooks for Identification of British Insects. Vol.8. Pt.3(diii). P.1107.

Yoder M.J. 2004. Revision of the North American species of the genus Entomacis (Hymenoptera: Diapriidae) // Canadian Entomologist. Vol.136. P.323-405.

Yoder M.J., Mikó I., Seltmann K.C., Bertone M.A., Deans A.R. 2010. A gross anatomy ontology for Hymenoptera // PLoS ONE. Vol.5. e15991. 